\title{
Innovation Capability Performance through Potential and Realized Absorptive Capacity: an Empirical Study in the West Java Mini Market
}

Sri Raharso ${ }^{1 凶}$

${ }^{1}$ Business Administration Department, Bandung State Polytechnic, Indonesia

\section{Article Information}

Article history:

Accepted: September 2020

Approved: January 2021

Published: March 2021

Keywords:

potential absorptive capacity

realized absorptive capacity

innovation capability

\begin{abstract}
This study explores how potential and realized absorptive capacity affects innovation capability. This study aims to empirically examine the path relationship between potential absorptive capacity, realized absorptive capacity, and innovation capability in mini market in West Java, thus enhance our understanding of the mechanism between absorptive capacity and innovation capability. The authors have conducted a survey among employees with a valid response from 597 respondents. Multiple regression was used to assess the research model. The results provide evidence to show that potential and realized absorptive capacity are positively related to innovation capability, but in different proportions, and potential absorptive capacity affects positively to realize absorptive capacity. This study will contribute in an acceptable way to highlight the effects and role of both the potential absorptive capacity and the realized absorptive capacity in their role as independent variables and the results of this in innovation capability in turn as a dependent variable.
\end{abstract}

How to Cite: Raharso, S. (2021). Innovation Capability Performance through Potential and Realized Absorptive Capacity: an Empirical Study in the West Java Mini Market. Jurnal Penelitan Ekonomi dan Bisnis, 6(1), 1-16. doi: https://doi.org/10.33633/jpeb.v6i1.4043

\begin{tabular}{lr}
\hline correspondence address: & ISSN \\
Jurusan Administrasi Niaga, Politeknik Negeri Bandung & 2442-5028 (print) 2460-4291 (online) \\
Jalan Gegerkalong Hilir, Ds. Ciwaruga, Kec. Parongpong, Bandung Barat & DOI: 10.33633/jpeb.v6i1.4043 \\
E-mail: harsopolban@gmail.com & C.
\end{tabular}




\section{INTRODUCTION}

In a complex business environment, innovation is an important resource for success and organizational life (Abbing, 2010; Canh et al., 2019; Cho \& Pucik, 2005). Innovation creates new business opportunities, forms new markets, and improves performance (Chen, 2017; Canh et al., 2019; Kim, 1997a, 1997b). Furthermore, innovation is needed to create and maintain a competitive advantage (Canh et al., 2019; Ionescu \& Dumitru, 2015; Ramdani et al., 2019; Eisenhardt \& Brown, 1999).

However, innovation doesn't happen in vacuum circumstances. Innovation will only occur if the company has innovation capabilities (Chen, 2017; Laforet, 2011; Han et al., 1998; Lawson \& Samson, 2001; Sözbilir, 2018; Teece et al., 1997; Yam et al., 2004; Cavusgil et al., 2003; Cohen \& Levinthal, 1990; Zahra \& George, 2002). Innovation capabilities provide the potential for effective innovation performance (Cavusgil et al., 2003). Innovation is a complex process and depends on a set of capabilities. These capabilities are scattered throughout the company structure, but all these capabilities can be aligned with a specific strategy. This set of capabilities forms a meta-capability known as innovation capability (Guan \& Ma, 2003; Wang et al., 2008). So, innovation capabilities are the result of a complementary set of capabilities (Wonglimpiyarat, 2010), which is the embryo of innovation.

Capability refers to specific resources that help companies maintain a competitive advantage or know-how and knowledge about how to use resources efficiently (Stalk et al., 1992; Grant, 1991). To maintain competitive advantage, firms require adjustment to changes in the external environment and require ownership of internal competencies (Andrews, 1971; Chandler, 1962; Hofer \& Schendel, 1978). Innovation capability refers to the internal ability to implement or apply new ideas, products, or processes (Burns \& Stalker, 1961). If the company has innovation capabilities at a high level, then the company can integrate innovations into the company's activities and will have lasting success (Burgelman et al., 2004). This is following the opinion of Zheng et al. (2011) and Grant (1991) which state that company capability is a precursor to performance, including innovation performance.

Innovation capability is influenced by internal and external factors of the company (Iddris, 2016). One of these factors is the absorptive capacity (Cohen \& Levinthal, 1990), which can be a lever of innovation capabilities (Lane et al., 2006; Medase \& Barasa, 2019; Gallegos \& Torner, 2018). The mechanism, recognizing the importance of external knowledge flows, is an important phenomenon in the process of building innovation capabilities (Zook \& Rigby, 2002). Companies gradually began to abandon the idea that more new knowledge is generated in internal processes within the company itself (Gans \& Stern, 2003). This can occur because the boundaries of an organization's knowledge reserves with external knowledge reserves are blurred (Teece, 1998). However, organizations do not automatically benefit from external knowledge flows even though the organization has exposed them (Cohen \& Levinthal, 1989, 1990). Moreover, the organization must develop the ability to recognize the value of external knowledge, and then assimilate and utilize that external knowledge for commercial purposes. That is, the organization must develop absorptive capacity, which consists of the components of acquiring and assimilating knowledge (often referred to as the dimension of potential absorptive capacity); and the component of transforming and exploiting knowledge, or what is often referred to as the dimension of realized absorptive capacity (Zahra \& George, 2002).

This study will explore the relationship between absorptive capacity and innovation capabilities in the modern grocery store business, better known as mini markets. Respondents in this study were mini market employees in West Java. Mini markets are a form of service business that is growing in Indonesia, especially West Java (Bella, 2019). Urgently, studies on innovation are more dominant in the manufacturing sector. Innovations in the service sector have received little attention (Johne \& Storey, 1998), including mini markets. Service characteristics make innovation in this sector different from the manufacturing sector (Drejer, 2004; De Jong et al., 2003, Miles, 2008). To the best of researchers' knowledge, studies on the relationship between absorptive and innovation capabilities in mini markets are still very rare. The number of mini markets in Indonesia is the largest in Southeast Asia, reaching 43,826 stores in 2017, with a growth rate of around $3.2 \%$, and each year around one thousand mini markets are added. Mini markets are also a significant contributor to the sales value of fast-moving 
consumer goods (FMCG), around 21\%; grew by $8 \%$ in 2018 , with $75 \%$ of consumers shopping in mini market formats, and visiting mini markets on average twice a week (Bella, 2019). This means that this situation is a challenge for mini market managers, if they do not understand what consumers want, then competitors will leave them (Hameli, 2018). Customers will easily move to another mini market if they are not satisfied.

However, the Covid-19 pandemic has weakened retail growth (Vader et al., 2020; Dinda, 2020; Alika, 2020). The Indonesian Retail Entrepreneurs Association (Aprindo) projects that in 2020 the retail industry will still grow, but will only reach around 1.5-2.0\% or weaken compared to the growth in 2019 which ranges from $8 \%$ to $8.5 \%$ (Dinda, 2020; Alika, 2020). Sales of modern retail stores are still low, only about $40-60 \%$ of total sales before the pandemic. This situation causes cash flow for modern retail stores to experience difficulties, considering that sales are lacking, but store operations are still running (Dinda, 2020; Alika, 2020). Pandemics also change consumer behavior (Buck et al., 2020). So, for mini markets to survive, continuous innovation is a proactive action that must be taken (D'Aveni, 2010; D'Aveni et al., 2010; Buck et al., 2020; Vader et al., 2020). This can happen if mini market employees have innovative capabilities.

Also, the literature studying absorptive capacity is more dominant at the firm level (Lane et al., 2006; Volberda et al., 2010), or sometimes at the alliance level (Lane \& Lubatkin, 1998; Lane et al., 2001) or the business unit level (Jansen et al., 2005; Tsai, 2001), ignoring the absorptive capacity at the individual level. Therefore, it is advisable to examine the concept at the individual level (Volberda et al., 2010; Lane et al., 2006). So, this study responds to the suggestions of these experts. Absorptive capacity at the individual level is determined by prior knowledge, cognition, and diversity of external networks (Jiménez-Castillo \& Sánchez-Pérez, 2013; Lowik et al., 2012), and is associated with favorable outcomes such as task performance (Deng et al., 2008; Park et al., 2007), knowledge creation (Matusik \& Heeley, 2005), and innovativeness (Lowik et al., 2012; Ter Wal et al., 2017; Tortoriello, 2014). Thus, the respondents in this study were individuals, mini market employees. This is in line with the statement of Cohen and Levinthal (1990) which states that individuals are at the forefront so that organizations can learn from external knowledge. The outcome, this study will add to the knowledge base of absorptive capacity from the perspective of individual roles.

Finally, this study also identifies the effect of the dimension of potential absorptive capacity on innovative capabilities, something other researchers rarely do. Existing empirical studies generally link absorptive capacity with innovative capabilities , or link potential absorptive capacity with realized absorptive capacity, and further link with innovative capabilities. This means that only the actual absorptive capacity directly affects innovation capability. One of the studies that we're able to prove the direct effect of potential absorptive capacity with innovation capability was conducted by Fosfuri and Tribó (2008) on 2,464 companies in Spain. So, this study will evaluate whether empirical studies of mini market employees in West Java support the relationship between potential absorptive capacity and innovative capabilities.

Cohen and Levinthal (1989) are experts who promote the term absorptive capacity, which is defined as a firm's ability to identify, assimilate, and exploit knowledge of the environment. Furthermore, Zahra and George (2002) reconceptualize the capacity to absorb and define it as a set of routine and organizational processes to acquire, assimilate, transform, and exploit knowledge to produce dynamic capabilities. Kim (1997a, 1997b) states that absorptive capacity is a firm's capacity to learn and solve problems.

The idea of absorptive capacity was obtained by Cohen and Levinthal (1989) after summarizing the insights from individual learning theory and then translated into organizational contexts. In particular, they noted the principle that prior knowledge (including basic skills and learning experiences) tends to enhance later learning because memory is associative. At the organizational level, they see the acquisition of new knowledge as mediated by individuals who become "gatekeepers" and "boundary-spanners". The gatekeeper's job is to filter and transfer knowledge, whereas boundary-spanners are those that go beyond organizational silos and help spread knowledge across all areas and levels of the organization (Zahra \& George, 2002; Daghfous, 2004a). Besides, the diversity of internal perspectives is also very important, because a very homogeneous internal view will result in resistance to external ideas (Cohen \& Levinthal, 1990). 
Cohen and Levinthal (1990) stated that the basis of absorptive capacity is the individual ability of organizational members. However, Zahra and George (2002) and Duchek (2013) state that absorptive capacity is an organizational construct. Zahra and George (2002) state that absorptive capacity is a dynamic capability related to the creation and utilization of knowledge. Dynamic terminology refers to an organization's capability to update competencies continuously so that it is in line with the changing business environment (Teece et al., 1997). This capability can be realized through two routes. First, Teece et al. (1997) emphasized the role of organizational resources and processes in achieving competitive advantage. Second, Grant (1996) emphasizes the role of knowledge as the most strategic resource for companies to realize these capabilities.

There are four components of absorptive capacity and they are grouped into two categories or dimensions, potential absorptive capacity (consisting of components of knowledge acquisition and assimilation) and realized absorptive capacity, consisting of components of knowledge transformation and exploitation (Zahra \& George, 2002). Knowledge acquisition refers to the company's capability in identifying and obtaining external knowledge that can support the company's operations. When new knowledge is identified and perceived as having value, this knowledge will be disseminated throughout the company boundaries (Daspit \& D'Souza, 2013). Whereas knowledge assimilation is defined as routine services and company processes that allow analyzing, process, interpret and understand information obtained from external resources. This capability helps companies analyze and interpret new knowledge in the context of existing knowledge (Jansen et al., 2005). In this stage, the company assesses whether the structure of the new knowledge is following the existing knowledge structure in the company (Daspit \& D'Souza, 2013). Furthermore, knowledge transformation is the capability of the company to develop and filter routines that facilitate combining existing knowledge with new knowledge and assimilating knowledge. This stage consists of modifying and adapting new knowledge and combining it with existing knowledge to explore new possibilities. This stage is considered the most relevant, which can be achieved by adding or removing knowledge, or by interpreting knowledge differently. Meanwhile, knowledge exploitation refers to routines that allow companies to filter, expand, and improve existing competencies or create new competencies by entering and transforming knowledge into company operations (Zahra \& George, 2002). Operationally, this stage uses knowledge to create value that is beneficial to companies and customers (Daspit \& D'Souza, 2013; Jansen et al., 2005; Zahra \& George, 2002). The potential absorptive capacity helps the realized absorptive capacity in developing various organizational and strategic capabilities (Duchek, 2013; Lev et al., 2009). The potential absorptive capacity represents the capability of creating knowledge, while the realized absorptive capacity allows companies to make new offerings based on the knowledge base that has been created (Flor \& Oltra, 2013).

Innovation capability is defined as the ability to continuously transform knowledge and ideas into new products, processes, and systems that provide benefits to the company and its interested parties (Lawson \& Samson, 2001). With innovation capabilities, companies can utilize the resources they have to develop new products or services (Tang et al., 2015). Choudhury (2010) states innovation capability as the ability to create new and useful knowledge based on previous knowledge. From a business perspective, useful knowledge is the knowledge that can produce new products or services that are beneficial to all parties.

Innovation capability is the company's ability to develop new products and/or new markets, through aligning strategic innovation orientation with innovative behavior and processes (Wang \& Ahmed, 2004), introducing new processes, products, or ideas in the organization to achieve success (Baregheh et al., 2009). For example, flexible organizational structure and design refer to organizational capabilities as dynamic capabilities, whereas individual creativity is the starting point for innovativeness (Amabile et al., 1996), and it is the firm capacity that constantly integrates, updates, builds, moves, and configures. Competencies and internal and external resources to seize and exploit opportunities (Teece, 2007).

Lawson and Samson (2001) state that organizational innovation capabilities arise from the skills and abilities that allow the application of resources, and reflect an ability to continuously transform knowledge and ideas into new products, new processes, and new systems that are beneficial to the company and all interested parties. Koc (2007) considers innovation capacity as a continuous improvement of all capabilities and resources owned by the company to explore and exploit opportunities to develop new products under market needs. 
Meanwhile, Chen (2009) states that innovation capability is a company's capability, which is inherent in processes, systems, and organizational structures, which can be applied to product and process innovation activities. A comprehensive definition from Ngo and O'Cass (2009) states that innovation capability is an integrative process of applying knowledge, skills, and collective company-owned resources to build innovation activities, in the form of technical innovations (products and/or services, and production process technology) as well as non-technical innovations (managerial, market, and marketing).

Innovation capability is a crucial factor in gaining a competitive advantage in turbulent market conditions. This capability directs the organization to develop continuous innovation, to respond to changes in the market environment (Slater et al., 2010). Innovation capabilities are embedded in all strategies, systems, and structures that support innovation in organizations (Gloet \& Samson, 2016). Innovation capabilities are structured through the main processes within the company and cannot be separated from other practices (Lawson \& Samson, 2001). Thus, the presence of this capability is considered a valuable asset for the company to provide and maintain a competitive advantage and is required in executing the company's strategy.

Innovation capabilities facilitate companies to rapidly introduce new products and adopt new systems and are also important as bait when the competition is ongoing. When hypercompetition is happening, this capability will provide a solution to win the competition. Innovation capability will be an asset to create innovative, competitive solutions. Sen and Egelhoff (2000) stated that innovation performance can be explained as a combination of assets and resources. This means that innovation requires resources, assets, and capabilities to direct the company to be successful in a turbulent environment. Therefore, Adler and Shenbar (1990) define innovation capability as the capacity to develop new products that satisfy market needs, the capacity to apply appropriate process technology to produce new products, the capacity to develop and adopt new products and process technologies to satisfy needs, in the future, and the capacity to respond to technological activities that can come at any time, and the capacity to respond to unexpected opportunities created by competitors.

Evidence states that innovation capability has a positive relationship with financial performance (Al-kalouti et al., 2020; Rajapathirana \& Hui, 2018; Han et al., 1998; Calantone et al. 2002; Lau et al. 2010; Tuominen \& Hyvönen, 2004; Hull \& Rothenberg, 2008; Jansen et al., 2006), as well as market share and innovation (Calantone et al. 2002; Lau et al. 2010; Tuominen \& Hyvönen, 2004). Companies with high innovation capabilities can develop innovative services and products and can cope with environmental changes during different phases of the business cycle (Matsuo, 2006). Experts argue that such companies will survive and succeed in various environmental conditions (Gao et al., 2007). Capability theory assumes that there are differences in capabilities that allow organizations to achieve lasting competitive advantage through a distinctive range of capabilities (Weerawardena \& McColl-Kennedy, 2002). In summary, in general, all capabilities are considered to be precursors of better performance (Zheng et al. 2011). Therefore, all modern companies need innovation capabilities (Aragón et al., 2014).

\section{Hypothesis Development \\ Relationship between Potential and Realized Absorptive Capacity}

Researchers argue that the ability to exploit external knowledge effectively is a critical factor for companies that want to improve innovation outcomes and company performance (Cohen \& Levinthal, 1990; Zahra \& George, 2002; Lane et al., 2006; Van Den Bosch et al., 2003; Lichtenthaler, 2009; Leal-Rodriguez et al., 2014). Some organizations must acquire knowledge from outside the organization if they are to maintain the rhythm of their activities (Zahra \& George, 2002). The stages are recognizing the value of external knowledge, acquiring external knowledge, recognizing the benefits of external knowledge, and acquiring it. Thus, the level of absorptive capacity is the result of developing potential absorptive capacity; although the potential absorptive capacity and the realized absorptive capacity are independent, they both perform complementary functions in absorbing new knowledge acquired from outside the organization.

Companies that have a high level of potential absorptive capacity do not always see an increase in performance (Zahra \& George, 2002). Conversely, the realized absorptive capacity or the ability of the 
organization to transform and exploit knowledge will be the mediator between the two variables, the potential absorptive capacity, and performance. Without the acquisition and assimilation of previous knowledge, the process of transformation and exploitation of previous knowledge would not be possible (Zahra \& George, 2002; AlbortMorant et al., 2018; Ali \& Park, 2016; Ben-Oz \& Greve, 2015; Leal-Rodriguez et al., 2015). In summary, the ability to absorb looks like a funnel, where the potential dimension ensures the novelty and diversity of the required knowledge, while the realized absorptive capacity is a symbol of the operation of new knowledge (Harmaakorpi \& Melkas, 2008).

Also, studies developed by Zahra and George (2002), Jansen et al. (2005), and Cepeda-Carrión et al. (2012) provide empirical evidence that the potential absorptive capacity is a precursor to the realized absorptive capacity. Concretely, they state that the organizational mechanism which refers to the potential absorptive capacity has a significant positive effect on the realized absorptive capacity. Zahra and George (2002) as well as Cohen and Levinthal (1990), state that the realized absorptive capacity is directed by the potential absorptive capacity. Therefore, based on the arguments previously described, the following hypothesis can be developed.

Hypothesis 1: The potential absorptive capacity is positively related to the realized absorptive capacity.

\section{Relationship between Realized Absorption Capacity and Innovation Capability}

Cohen Levinthal (1990) proposed that the use of external knowledge acquired by an organization is a major determinant of innovation capabilities. The study of Zahra and George (2002) states that there is a significant positive relationship between absorptive capacity and innovation, and together these two concepts are the basic foundation of organizational competitive advantage. The results of the empirical study of Knudsen and Roman (2004) also found the ability of absorptive capacity to predict innovation capabilities. On the other hand, Caloghirou et al. (2004) investigated the extent to which the interaction of the organization's internal capabilities and external knowledge resources affects the level of organizational innovativeness. They found that absorptive capacity played a significant role.

Next, Nieto and Quevedo (2005) analyzed the effect of three variables related to industrial structure (capacity to absorb, technological opportunities, and abundance of knowledge) on innovation efforts developed by companies, carried out on 406 innovative companies in Spain. As a result, absorptive capacity determines innovation effort more than the other two industrial structure variables. Besides, absorptive capacity is also a moderating variable between technological opportunities and innovation efforts. Absorptive capacity facilitates the transfer of knowledge, which will be utilized to build technical and managerial innovation capabilities (Minbaeva et al., 2003). In other words, the study proved the positive effect of absorptive capacity on innovation capabilities.

Other empirical studies also provide support for the relationship between absorptive capacity with innovation capabilities and innovation performance (Hughes et al., 2014; Wu \& Shanley, 2009; Subramaniam \& Youndt, 2005; Daghfous, 2004b). One reason is that absorptive capacity promotes the speed, frequency, and magnitude of innovation (Kostopoulos et al., 2011). High absorptive capacity coupled with the advantages of first movers, rapid response to customers, and avoidance of the "locking" and "competency trap" effects (Zahra \& George, 2002; Hamel, 1991), will facilitate companies in obtaining superior innovation performance. In fact, of the four components of absorptive capacity, the last two components, namely: transformation and exploitation, are components that directly affect innovation capabilities (Zahra \& George, 2002). That is, the dimension of realized absorptive capacity has a relationship with innovation capability (Cepeda-Carrión et al., 2012; Xun \& Xuehan, 2014). Therefore, a hypothesis can be made as follows.

Hypothesis 2: Realized absorptive capacity is positively related to innovation capability.

\section{Relationship between Potential Absorptive Capacity and Innovation Capability}

Potential absorptive capacity is a source of competitive advantage over innovation, especially when an efficient internal knowledge flow exists to reduce the gap between potential and realized absorptive capacity. The potential absorptive capacity allows the company to identify and assimilate the external knowledge flows required in the innovation process. The potential absorptive capacity is conceptualized as a mapping from the flow of useful 
external knowledge to the information available internally (Fosfuri \& Tribó, 2008). Zahra and George (2002) admit that the potential absorptive capacity gets less empirical studies than the realized absorptive capacity.

Fosfuri and Tribó (2008) stated that companies with high potential absorptive capacity get more sales from new products or products that have been perfected. This influence will be greater when the internal information flow becomes more efficient. This study supports the argument of Zahra and George (2002) which states that the potential absorptive capacity is a necessary condition for achieving a competitive advantage in innovation, but companies also need to develop the ability to transform and exploit external knowledge to fully benefit from absorptive capacity.

The accumulation of potential absorptive capacity will be faster if it is supported by internal events. For example, major changes that include serious modifications in organizational design, strategy, and marketing can improve the potential level of absorptive capacity. Furthermore, proper internal reshaping will make the company more outward-looking and more "welcome" to internal information. So, when a company experiences a crisis, it is not always negative (Kim, 1998). Crises can trigger changes in attitudes towards external knowledge (Winter, 2000; Huber, 1991). This is especially useful for companies that have a "not found here" syndrome (Allen \& Katz, 1982). Based on these studies, the following hypothesis can be developed.

Hypothesis 3: Potential absorptive capacity is positively related to innovation capability

\section{METHOD}

This cross-sectional study is descriptive and associative, with the unit of analysis being mini market employees in West Java. The study population was all employees who worked in mini markets in West Java. The sample is determined based on the analysis technique used, namely: multiple regression (Hair et al., 1998; 2010), with a minimum quota of 500 respondents. This amount has met the requirements for multivariate research (Hair et al., 1998; 2010). Samples were obtained by the accidental sampling technique, by visiting each mini market and asking the employees' willingness at that time to participate in this research.

A Likert scale questionnaire (Soedibjo, 2013) was used to obtain primary data, with a value of $1=$ strongly disagree and $5=$ strongly agree. The absorptive capacity (AC) variable is divided into four components, namely: acquisition and assimilation, referred to as potential $\mathrm{AC}$; and transformation and exploitation, referred to as realized AC (Zahra \& George, 2002). The acquisition component consists of four statement items, examples of items are: The employees of this mini market are happy to accept suggestions from consumers/the public. The assimilation component consists of three statement items, for example, Employees at this mini market participate in solving problems. Meanwhile, the transformation component consists of three statement items, for example, Employees in this mini market are trying to improve existing business processes. The exploitation component, consists of three statement items, for example, Employees take advantage of information/knowledge to get new opportunities. Finally, the variable innovation capability is mono-dimensional, modified from Lin (2007), consisting of seven statement items, for example, This mini market often generates new ideas.

To test the validity of the measuring instrument, two kinds of tests were made, validity, and reliability tests. Furthermore, the identification of relationship patterns between variables can be obtained from the empowerment of multiple regression analysis (Santoso, 2002; Hair et al., 1998; 2010); useful for proving the three research hypotheses developed in this study.

\section{RESULT AND DISCUSSION}

This research was conducted on mini market employees in West Java, covering six districts and five cities. The total respondents were 597 people. The respondents work in Alfamart mini market as much as 47.7\%; Indomaret 35.3\%; Yomart 10.2\%; and the rest in other mini markets. Based on gender, the number of male respondents did not differ much from female respondents, respectively $52.3 \%$ and $47.7 \%$. Mini market employees who were respondents in this study were dominated by those who had a service period of $<2$ years, as much as $57.6 \%$. Respondents with a work period of $2-5$ years amounted to $37.5 \%$, and the rest had a working period of more 
than five years. This means that almost half of the respondents have sufficient work experience. Also, respondents are part of the millennial generation, because they are dominated by those aged $<30$ years, as much as $93 \%$; the rest was over thirty. Finally, based on education level, respondents generally graduated from SMA/SMK, as much as 92.8\%; the rest are Diploma or Bachelor's graduates.

Table 1 shows the three variables used in this study are reliable because they have a value of $\alpha>0.70$ (Sekaran, 2007; Robinson et al., 1991). Besides, the table shows the potential absorptive capacity (potential AC) has an average value of 4.04; realized absorptive capacity (realized AC) 3.98, and innovation capability 3.5; all are included in the "high" class if they are classified into five classes (included in the range 3.41-4.20). Judging from the standard deviation, all variables has a standard deviation that is within a tolerable range, namely: a maximum of $20 \%$ of the average value (Santoso, 2002). This means that the answers of mini market employees in West Java tend to be homogeneous, not too diverse. Next, the correlation between variables is significant, this shows that this study meets the requirements of criterion-related validity or predictive validity; because all independent variables have a significant relationship with the dependent variable (Das et al., 2008). Potential AC has a positive and significant correlation with realized AC $(0.625 ; \mathrm{p}<0.01)$ and with innovation capability $(0.548 ; \mathrm{p}<0.01)$. Realized $\mathrm{AC}$ has a positive and significant correlation with innovation capability $(0.666 ; \mathrm{p}<0.01)$.

Table 1. Reliability, Average, and Correlation among Variables

\begin{tabular}{l|l|c|c|c|c|c|c}
\hline & & $\begin{array}{c}a \\
\text { Cronbach }\end{array}$ & Aver. & $\begin{array}{c}\text { Dev. } \\
\text { Stand. }\end{array}$ & $\mathbf{1}$ & $\mathbf{2}$ & $\mathbf{3}$ \\
\hline $\mathbf{1}$ & P. AC & 0.772 & 4.04 & 0.45 & 1 & $0.625^{* *}$ & $0.548^{* *}$ \\
\hline $\mathbf{2}$ & R. AC & 0.754 & 3.98 & 0.47 & & 1 & $0.666^{* *}$ \\
\hline $\mathbf{3}$ & IC & 0.825 & 3.95 & 0.51 & & & 1 \\
\hline **. The correlation is significant at the 0.01 level (2-tailed); N=597; Scale: $1-5$ & & \\
P. AC: Potential AC; R. AC: Realized AC; IC: Innovation Capability &
\end{tabular}

The next step is to test the three hypotheses proposed in this study. Figure 1 shows the results of multiple regressions between variables made in the form of a structural model with path coefficients. It is seen that the potential AC significantly affects realized AC $(\beta=0.625 ; \mathrm{t}=19.544 ; \mathrm{p}<0.05)$, and can explain $39.13 \%$ of the variation in realizing $A C$, the rest is explained by other variables. Potential $A C$ also has a significant effect on innovation capability $(\beta=0.216 ; t=5.663 ; p<0.05)$, and together with realized AC was able to explain $47.0 \%$ of the variation in innovation capability; the rest is explained by other variables. As hypothesized, realized AC also significantly affected innovation capability $(\beta=0.530 ; t=13.883 ; \mathrm{p}<0.05)$. In other words, all hypotheses are supported by empirical data.

The study developed by Jansen et al. (2005) also provides empirical evidence that the potential absorptive capacity is a precursor to the realized absorptive capacity. Concretely, they state that the organizational mechanism which refers to the potential absorptive capacity has a significant positive effect on the realized absorptive capacity. Zahra and George (2002) and Cohen and Levinthal (1990) stated that the realized absorptive capacity is directed by the potential absorptive capacity. Potential absorptive capacity is an organizational process of absorbing external knowledge through acquisition and assimilation, but the transformation and application of this knowledge will not automatically occur (Kang \& Lee, 2017). Meanwhile, the realized absorptive capacity combines processes that utilize external knowledge to support organizational goals, which can be achieved through transformation and exploitation activities. Cassol et al. (2016) explained that the potential absorptive capacity is an instrument for obtaining and assimilating knowledge at a relatively dormant level until there is a reason to use it, then the knowledge will be at an active level, called the realized absorptive capacity.

This study proves that there is a positive and significant effect of the realized absorptive capacity on innovation capabilities $(\beta=0.530 ; \mathrm{t}=13.883 ; \mathrm{p}<0.05)$, and together with the potential absorptive capacity, it can explain $47 \%$ of the variation in innovation capabilities. In line with the results of the study by Cepeda-Carrion et al. (2012), which proved that there was a significant and positive influence on innovativeness, with a path coefficient of 0.529 and was able to explain $28 \%$ of the variation in innovativeness. That is, the results of this study are similar to their results. The difference is that this study uses two dimensions of absorptive capacity to explain the existing variations in innovation capabilities. 


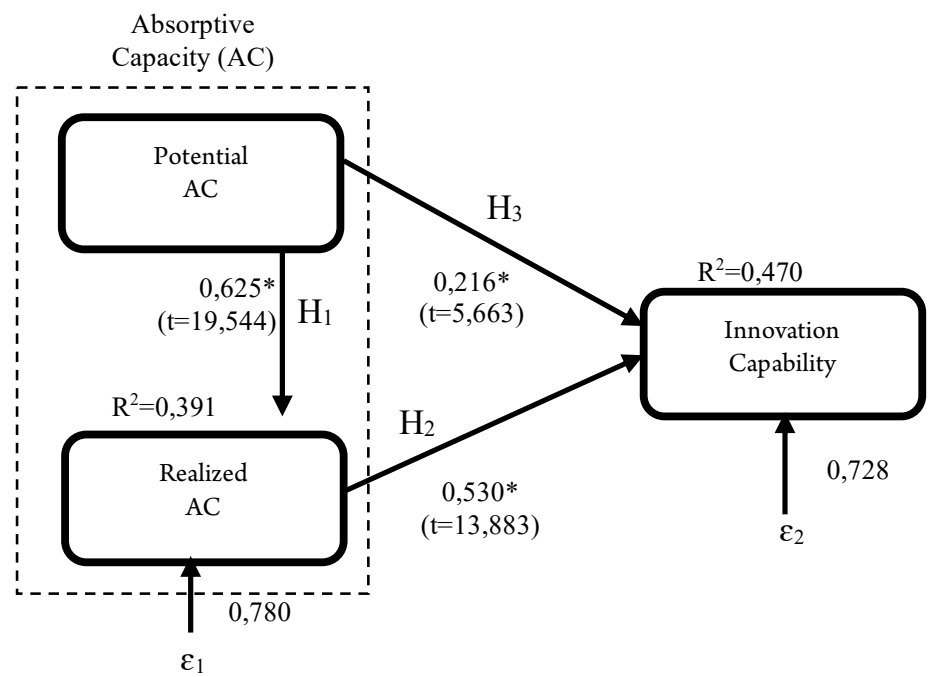

Figure 1. Structural Model with Path Coefficients

The realized absorptive capacity is one of the two dimensions of absorptive capacity suggested by Zahra and George (2002). According to their model, the realized absorptive capacity is a precursor to innovation. So, because innovation will only occur if there is innovation capability, the realized absorptive capacity is a precursor to innovation capability. Thus, this research is in line with the original model from Zahra and George (2002), which assumes the process of absorptive capacity as a sequential or linear process, starting from acquisition, assimilation, transformation, and exploitation. Kostopoulos et al. (2011) stated that absorptive capacity determines the speed, frequency, and magnitude of innovation capability.

This empirical study was successful in proving the existence of a positive and significant effect of potential absorptive capacity on innovation capabilities in mini markets $(\beta=0.216 ; \mathrm{t}=5.663 ; \mathrm{p}<0.05)$. This study supports the argument of Zahra and George (2002) which states that the potential absorptive capacity is a necessary condition for achieving a competitive advantage in innovation. In the context of this research, competitive advantage is not in the form of innovation but in innovation capability, which has been known as a precursor to innovation (Laforet, 2011; Chen, 2017). The difference is that the absorptive capacity model from Zahra and George (2002) does not explicitly explain the direct route from the potential absorptive capacity to innovation capability, but must go through the realized absorptive capacity mediator. The results of research by Fosfuri and Tribó (2008) identified companies with a high potential absorptive capacity that had a good performance in producing new products and enhanced products, and the outcome was better sales. The results of the study by Xun and Xuehan (2014) also prove that there is a positive and significant effect of the four components of Zahra and George's (2002) absorptive capacity on knowledge transfer efficiency and innovation performance.

This can happen because the absorbing capacity is not linear as suggested by Zahra and George (2002). This non-linear process is supported by Todorova and Durisin (2007), Volberda et al. (2010), as well as Aribi and Dupouët (2016). Todorova and Durisin (2007) state that the transformation process, which is a component in the realized absorptive capacity of Zahra and George (2002), is complementary to the assimilation process. When the assimilation process cannot be carried out because the cognitive structure does not change, or when new knowledge does not match the existing knowledge structure, it is not assimilation that occurs but transformation. That is, empirically what happens between mini market employees in West Java is knowledge exploration and exploitation (March 1991). In other words, the potential absorptive capacity of Zahra and George (2002) is also perceived to contain a transformation component (from Todorova \& Durisin, 2007), so that it can significantly influence innovation capabilities. Although this effect is not as big as the effect of realized absorptive capacity on innovation capability $(\beta=0.216$ compared to $\beta=0.530)$; however, it is in line with the statement of Zahra and George (2002) which states that the contribution of the realized absorptive capacity to innovation capability is greater than the potential absorptive capacity. However, they made no further explanation. According to Xun and Xuehan (2014), this can happen because the components of the potential and realized absorptive capacity have different effects on knowledge transfer activities. 


\section{CONCLUSION AND RECOMMENDATION}

Empirically, the research has succeeded in proving all the hypotheses built to explore the relationship between the dimensions of absorptive capacity and innovation capabilities among mini market employees in west java. First, the potential absorptive capacity positively and significantly affects the realized absorptive capacity. Furthermore, the realized absorptive capacity also positively and significantly affects innovation capabilities. Third, this study shows empirical evidence of a positive and significant effect of potential absorptive capacity on innovation capabilities. This latter empirical evidence is scarce. However, this also has the consequence of providing a more robust database of absorptive capacity concepts. This includes exploring the absorptive capacity dimension of other researchers. Especially researchers who state that absorptive capacity is non-linear.

\section{REFERENCES}

Abbing, E. R. (2010). Brand-driven Innovation. Lausanne, SA: AVA Publishing.

Adler, P.S., \& Shenbar, A. (1990). Adapting your technological base: The organizational challenge. Sloan Management Review, 25, 25-37.

Albort-Morant, G.; Henseler, J.; Cepeda-Carrión, G. \& Leal-Rodríguez, A.L. (2018). Potential and realized absorptive capacity as complementary drivers of green product and process innovation performance. Sustainability, 10, 381 .

Ali, M. \& Park, K. (2016). The mediating role of an innovative culture in the relationship between absorptive capacity and technical and non-technical innovation. Journal of Business Research, 69(5), 16691675.

Alika, R. (2020). Imbas Pandemi, Bisnis Retail Diramal Hanya Tumbuh 2\% Tahun Ini. Available at: https://katadata.co.id/ekarina/berita/5f35fe8fce960/imbas-pandemi-bisnis-retail-diramal-hanyatumbuh-2-tahun-ini. 25 December 2020.

Al-kalouti, J., \& Kumar, V., Kumar, N., Garza-Reyes, J.A., Upadhyay, A., \& Zwiegelaar, J.B. (2020). Investigating innovation capability and organizational performance in service firms. Strategic Change, 29, 103113. DOI: $10.1002 /$ jsc.2314.

Allen, T.J., \& Katz, R. (1982). Investigating the not-invented-here (NIH) syndrome: a look at the performance, tenure, and communications patterns of $50 \mathrm{R} \& \mathrm{D}$ project groups. R\&D Management, 12(1), 7-19.

Amabile, T., Conti, R., Coon, H., Lazen B. J., \& Herron, M. (1996). Assessing the work environment for creativity. Academy of Management Journal, 39 (5), 1154-1184.

Andrews, K.R. (1971). The Concept of Corporate Strategy. Homewood, IL: Irwin.

Aragón, M.I.B., Jiménez, D.J., \& Valle, R.S. (2014). Training and performance: the mediating role of organizational learning. BRQBusiness Research Quarterly, 17(3), 161-173.

Aribi, A., \& Dupouët, O. (2016). Absorptive capacity: a non-linear process. Knowledge Management Research \& Practice, 14(1), 15-26. doi:10.1057/kmrp.2014.17.

Baregheh, A., Rowley, J. \& Sambrook, S. (2009). Towards a multidisciplinary definition of innovation. Management Decision, 47(8), 1323-1339.

Bella, A. (2019). Jumlah mini market Indonesia terbanyak di Asia Tenggara. Download 02-05-2020, https://marketeers.com/jumlah-mini market-indonesia-terbanyak-di-Asia-Tenggara/

Ben-Oz, C. \& Greve, H.R. (2015). Short- and long-term performance feedback and absorptive capacity. Journal of Management, 41(7), 1827-1853.

Buck, R., Coggins, B., Exarchos, P., Francis, T., Henrich, J., Kelly, G., Kohli, S., McInerney, P., Wachinger, T., \& Zipser, D. (Eds.). (2020). Perspectives on retail and consumer goods. McKinsey \& Company, Number

8, August

2020 .

Available

at: 
https://www.mckinsey.com/ /media/McKinsey/Industries/Retail/Our\%20Insights/Perspectives \%20on\%20retail\%20and\%20consumer\%20goods\%20Number\%208/Perspectives-on-Retail-andConsumer-Goods_Issue-8.pdf. 25 December 2020.

Burgelman, R.A., Christensen, C.M., \& Wheelwright, S.C. (2004). Strategic Management of Technology and Innovation. Irwin: McGraw-Hill.

Burns, T., \& Stalker, M.G. (1961). The Management of Innovation. London: Tavistock.

Calantone, R. J., Cavusgil, S. T., \& Zhao, Y. (2002). Learning orientation, firm innovation capability, and firm performance. Industrial Marketing Management, 31(6), 515-524. DOI: 10.1016/S00198501(01)00203-6.

Caloghirou, Y., Kastelli, I., \& Tsakanikas, A. (2004). Internal capabilities and external knowledge sources: complements or substitutes for innovative performance? Technovation, 24, 29-39.

Canh, N.T., Liem, N.T., Thu, P.A., \& Khuong, N.V. (2019). The impact of innovation on the firm performance and corporate social responsibility of Vietnamese manufacturing firms. Sustainability, 11, 3666; doi: $10.3390 /$ su11133666.

Cassol, A., Reis, C., \& Lima, R. (2016). Redefining the Relationship between Intellectual Capital and Innovation: The Mediating Role of Absorptive Capacity. Brazilian Administration Review, 13(4), 1-25.

Cavusgil, S.T., Calantone, R.J., \& Zhao, Y. (2003). Tacit knowledge transfer and firm innovation capability. Journal of Business \& Industrial Marketing, 18(1), 6-21. doi:10.1108/08858620310458615.

Cepeda-Carrión, G., Cegarra-Navarro, J.G., \& Leal-Millan, A.G. (2012). Finding the hospital-in-the-home units' innovativeness. Management Decision, 50(9), 1596-1617. DOI 10.1108/00251741211266705

Chandler, A. (1962). Strategy and Structure. Cambridge, Mass: MIT Press.

Chen, C.-J. (2009). Technology commercialization, incubator, and venture capital, and new venture performance. Journal of Business Research, 62(1), 93-103.

Chen, S. (2017). The relationship between innovation and firm performance: a literature review. Advances in Computer Science Research, 82, 648-652.

Cho, H.J., \& Pucik, V. (2005). Relationship between innovativeness, quality, growth, profitability, and market value. Strategic Management Journal, 26, 555-575.

Choudhury, J. (2010). Performance impact of intellectual capital: A study of Indian it sector. International Journal of Business and Management, 5(9), 72-80.

Cohen, W.M. \& Levinthal, D.A. (1989). Innovation and learning: the two faces of R\&D. The Economic Journal, 99, 569-596.

Cohen, W.M. \& Levinthal, D.A. (1990). Absorptive capacity: a new perspective on learning and innovation. Administrative Science Quarterly, 35(1), 128-152.

D'Aveni, R.A. (2010). Hypercompetition. New York: Simon \& Schuster.

D'Aveni, R.A., Dagnino, G.B., \& Smith, K.G. (2010). The age of temporary advantage. Strategic Management Journal, 31(13), 1371-1385.

Daghfous, A. (2004a). Knowledge management as an organizational innovation: an absorptive capacity perspective and a case study. International Journal of Innovation and Learning, 1(4), 409-422.

Daghfous, A. (2004b). Absorptive capacity and the implementation of knowledge-intensive best practices. SAM Advanced Management Journal, 69(2), 21-27.

Das, A., Paul, H., \& Swierczek, F.W. (2008). Developing and validating total quality management (TQM) constructs in the context of Thailand's manufacturing industry. Benchmarking: an International Journal, 15(1), 52-72.

Daspit, J.J. \& D'Souza, D.E. (2013). Understanding the multi-dimensional nature of absorptive capacity. Journal of Managerial Issues, 25(3), 299-316. 
De Jong, J., Bruins, A., Dolfsma, W., \& Meijaard, J. (2003). Innovation in services firms explored: What, how and why? EIM Report, Zoetermeer.

Deng, X., Doll, W.J., \& Cao, M. (2008). Exploring the absorptive capacity to innovation/productivity link for individual engineers engaged in IT-enabled work. Information and Management, 45(2), 75-87.

Dinda, S. (2020). Aprindo Proyeksikan 2020 Ritel Tumbuh Melemah. Available at: https://investor.id/business/aprindo-proyeksikan-2020-ritel-tumbuh-melemah. 25 December 2020.

Drejer, I. (2004). Identifying innovation in surveys of services: a Schumpeterian perspective. Research Policy, 33(3), 551-562.

Duchek, S. (2013). Capturing absorptive capacity: a critical review and future prospects. Schmalenbach Business Review, 65(3), 312-329.

Eisenhardt, K.M., \& Brown, S.L. (1999). Patching: restitching business portfolios in dynamic markets. Harvard Business Review, 77(3), 72-82.

Flor, M.L. \& Oltra, M.J. (2013). An exploratory analysis of the relationship between absorptive capacity and business strategy. Technology Analysis \& Strategic Management, 25(9), 1103-1117.

Fosfuri, A. \& Tribó, J.A. 2008. Exploring the antecedents of potential absorptive capacity and its impact on innovation performance. Omega, 36(2), 173-187.

Gallegos, J.F.D.C., \& Torner, F.M. (2018). Absorptive capacity and innovation in low-tech companies in emerging economies. Journal of Technology Management \& Innovation, 13(2), 1-10.

Gans, J. \& Stern, S., 2003. The product market and the market for "ideas": commercialization strategies for technology entrepreneurs. Research Policy 32(2), 333- 350.

Gao, G.Y., Zhou, K.Z. \& Yim, C.K. (2007). On what should firms focus in transitional economies? A study of the contingent value of strategic orientations in China. International Journal of Research in Marketing, 24(1), 3-15.

Gloet, M., \& Samson, D. (2016). Knowledge management and systematic innovation capability. International Journal of Knowledge Management (IJKM), 12(2), 54-72.

Grant, R.M. (1991). The resource-based theory of competitive advantage: implications for strategy. California Management Review, 22, 114-135.

Grant, R.M. (1996). Toward a knowledge-based theory of the firm. Strategic Management Journal, 17(2), 109122.

Guan, J. \& Ma, N. (2003). Innovative capability and export performance of Chinese firms. Technovation, 23(9), 737-747.

Hair, Jr., Joseph F., Anderson, R.E., Tatham, R.L., \& Black, W.C. (1998). Multivariate data analysis with reading. New Jersey: Prentice-Hall.

Hair, Jr., Joseph F., Black, William C., Babin, Barry J., \& Anderson, Rolph E. (2010). Multivariate Data Analysis: a global perspective. New Jersey: Pearson.

Hamel, G. (1991). Competition for competence and inter partner learning within international strategic alliances. Strategic Management Journal, 12(S1), 83-103.

Hameli, K. (2018). A literature review of the retailing sector and business retailing types. ILIRIA International Review, 8, 1-21.

Han, J.K., Kim, N. \& Srivastava, R. (1998). Market orientation and organizational performance: is innovation a missing link? Journal of Marketing, 62(4), 30-45.

Harmaakorpi, V. \& Melkas, H. (2008). Data, information, and knowledge in regional innovation networks: Quality considerations and brokerage functions. European Journal of Innovation Management, 11, 103124. 
Hofer, C. \& Schendel, D.E. (1978). Strategy Formulation: Analysis Concepts. Saint Paul Conn., MN: West Publishing Co.

Huber, G. (1991). Organizational learning: the contributing processes and the literature. Organization Science, 2, 88-115.

Hughes, M., Morgan, R.E., Ireland, R.D., \& Hughes, P. (2014). Social capital and learning advantages: a problem of absorptive capacity. Strategic Entrepreneurship Journal, 8(3), 214-233.

Hull, C.E. \& Rothenberg, S. (2008). Firm performance: the interactions of corporate social performance with innovation and industry differentiation. Strategic Management Journal, 29(7), 781-789.

Iddris, F. (2016). Innovation capability: A systematic review and research agenda. Interdisciplinary Journal of Information, Knowledge, and Management, 11, 235-260.

Ionescu, A., \& Dumitru, N.R. (2015). The role of innovation in creating the company's competitive advantage. Ecoforum, 4(1/6), 99-104.

Jansen, J.J.P., van den Bosch, F.A.J., \& Volberda, H.W. (2006). Exploratory innovation, exploitative innovation, and performance: effects of organizational antecedents and environmental moderators. Management Science, 52(11), 1661-1674.

Jansen, J.J.P., Van Den Bosch, F.A.J., \& Volberda, H.W. (2005). Managing potential and realized absorptive capacity: how do organizational antecedents matter? Academy Management Journal, 48(6), 9991015.

Jiménez-Castillo, D., \& Sánchez-Pérez, M. (2013). Nurturing employeesé market knowledge absorptive capacity through unified internal communication and integrated information technology. Information and Management, 50(2/3), 76-86.

Johne, A., \& Storey, C. (1998). New Service Development: A review of the literature and annotated bibliography. European Journal of Marketing, 32 (3-4), 184-251.

Kang, M., \& Lee, M. (2017). Absorptive Capacity, Knowledge Sharing, and Innovative Behaviour of R\&D Employees. Technology Analysis \& Strategic Management, 29(2), 219-232.

Kim, L. (1998). Crisis construction and organizational learning: capability building in catching-up at Hyundai Motor. Organization Science, 9, 506-21.

Kim, L. (1997a). The dynamics of Samsung's technological learning in semiconductors. California Management Review, 39, 86-100.

Kim, L. (1997b). Imitation to Innovation: the dynamics of Korea's technological learning. Boston, MA, USA: Harvard Business Press.

Knudsen, H.K., \& Roman, P.M. (2004). Modeling the use of innovations in private treatment organizations: the role of absorptive capacity. Journal of Substance Abuse Treatment, 26, 353-61.

Koc, T. (2007). Organizational determinants of innovation capacity in software companies. Computers and Industrial Engineering, 53, 373-385.

Kostopoulos, K., Papalexandris, A., Papachroni, M. \& Ioannou, G. (2011). Absorptive capacity, innovation, and financial performance. Journal of Business Research, 64(12), 1335-1343.

Laforet, S. (2011). A framework of organizational innovation and outcomes in SMEs. International Journal of Entrepreneurial Behavior \& Research, 17(4), 380-408.

Lane, P.J., \& Lubatkin, M. (1998). Relative absorptive capacity and interorganizational learning. Strategy Management Journal, 19(5), 461-477.

Lane, P.J., Koka, B.R., \& Pathak, S. (2006). The reification of absorptive capacity: a critical review and rejuvenation of the construct. Academy Management Review, 31(4), 833-863.

Lane, P.J., Salk, J.E., \& Lyles, M.A. (2001). Absorptive capacity, learning, and performance in international joint ventures. Strategy Management Journal, 22(12), 1139-1161. 
Lau, A. K. W., Yam, R. C. M., \& Tang, E. P. Y. (2010). The impact of technological innovation capabilities on innovation performance: An empirical study in Hong Kong. Journal of Science and Technology Policy in China, 1(2), 163-186. doi:10.1108/17585521011059893.

Lawson, B. \& Samson, D. (2001). Developing innovation capability in organizations: a dynamic capabilities approach. International Journal of Innovation Management, 5(3), 377-400.

Leal-Rodriguez, A.L., Roldán, J.L., Ariza-Montes, J.A., \& Leal-Millán, A. (2014). From potential absorptive capacity to innovation outcomes in project teams: The conditional mediating role of the realized absorptive capacity in a relational learning context. International Journal of Project Management, 32, 894-907.

Leal-Rodrıguez, A.L., Eldridge, S., Roldán, J.L., Leal-Millán, A.G. \& Ortega-Gutierrez, J. (2015). Organizational unlearning, innovation outcomes, and performance: the moderating effect of firm size. Journal of Business Research, 68(4), 803-809.

Lev, S., Fiegenbaum, A. \& Shoham, A. (2009). Managing absorptive capacity stocks to improve performance: empirical evidence from the turbulent environment of Israeli hospitals. European Management Journal, 27(1), 13-25.

Lichtenthaler, U. (2009). Absorptive capacity, environmental turbulence, and the complementarity of organizational learning processes. Academy of Management Journal, 52, 822-846.

Lin, H.F. (2007). Knowledge sharing and firm innovation capability: an empirical study. International Journal of Manpower, 28(3), 315-332.

Lowik, S., Kraaijenbrink, J., \& Groen, A.J. (2012). The effects of prior knowledge, networks, and cognitive style on individuals' absorptive capacity. Academy of Management Proceeding, http://dx.doi.org/10.5465/AMBPP.2012.197.

March, J. (1991). Exploration and exploitation in organizational learning. Organization Science, 2(1), 71-87.

Matsuo, M. (2006). Customer orientation, conflict, and innovativeness in Japanese sales departments. Journal of Business Research, 59(2), 242-250.

Matusik, S.F., \& Heeley, M.B. (2005). Absorptive capacity in the software industry: identifying dimensions that affect knowledge and knowledge creation activities. Journal of Management, 31(4), 549-572. DOI: $10.1177 / 014920630427229$.

Medase, K., \& Barasa, L. (2019). Absorptive capacity, marketing capabilities, and innovation commercialization in Nigeria. European Journal of Innovation Management, 22(5), 790-820. DOI 10.1108/EJIM-092018-0194.

Miles, I. (2008). Patterns of innovation in service industries. IBM Systems Journal, 47(1), 115-128.

Minbaeva, D., Pedersen, T., Björkman, I., Fey, C.F., \& Park, H.J. (2003). MNC knowledge transfer, subsidiary absorptive capacity, and HRM. Journal of International Business Studies, 34, 586-99.

Ngo, L.V., \& O'Cass, A. (2009). Creating value offerings via operant resource-based capabilities. Industrial Marketing Management, 38, 45-59.

Nieto, M. \& Quevedo, P. (2005). Absorptive capacity, technological opportunity, knowledge spillovers, and innovative effort. Technovation, 25, 1141-57.

Park, J.-H., Suh, H.-J., \& Yang, H.-D. (2007). The perceived absorptive capacity of individual users in the performance of Enterprise Resource Planning (ERP) usage: the case for Korean firms. Information and Management, 44(3), 300-312.

Rajapathirana, R.P.J., \& Hui, Y. (2018). Relationship between innovation capability, innovation type, and firm performance. Journal of Innovation \& Knowledge, 3, 44-55. DOI.org/10.1016/j.jik.2017.06.002 2444-569X.

Ramdani, B., Binsaif, A., \& Boukrami, E. (2019). Business model innovation: a review and research agenda. New England Journal of Entrepreneurship, 22(2), 89-108. DOI 10.1108/NEJE-06-2019-0030. 
Robinson, J.P., Shaver, P.R., \& Wrightsman, L.S. (1991). Criteria for scale selection and evaluation. In Robinson, J. P., Shaver, P. R., \& Wrightsman, L. S. (eds.) 1991. Measures of personality and social psychological attitudes. San Diego, CA.: Academic Press.

Santoso, S. (2002). Buku Latihan SPSS Statistik Multivariat. Jakarta: Elex Media Komputindo.

Sekaran, U. (2007). Metode Penelitian untuk Bisnis. Jilid 1 \& 2. Diterjemahkan oleh Kwan Men Yon. Jakarta: Salemba Empat.

Sen, F.K., \& Egelhoff, W.G. (2000). Innovative capabilities of a firm and the use of technical alliances. IEEE Transactions on Engineering Management, 47(2), 174-183.

Slater, S.F., Hult, G.T.M., \& Olson, E.M. (2010). Factors influencing the relative importance of marketing strategy creativity and marketing strategy implementation effectiveness. Industrial Marketing Management, 39(4), 551-559.

Soedibjo, B.S. (2013). Pengantar Metode Penelitian. Bandung: Unas Pasim.

Sözbilir, F. (2018). Innovation capacity and innovation performance in terms of the educational level of managers. Journal of Business Research-Türk, 10(2), 1-12.

Stalk, G., Evans, P. \& Shulman, L. (1992). Competing on capabilities: the new rules of corporate strategy. Harvard Business Review, March-April, 57-69.

Subramaniam, M. \& Youndt, M.A. (2005). The influence of intellectual capital on the types of innovative capabilities. Academy of Management Journal, 48(3), 450-463.

Tang, T.-W., Wang, M.C.-H., \& Tang, Y.-Y. (2015). Developing service innovation capability in the hotel industry. Service Business, 9(1), 97-113.

Teece, D.J. (1998). Capturing value from knowledge assets: the new economy, markets for know-how, and intangible assets. California Management Review, 40(3), 55-79.

Teece, D.J. (2007). Explicating dynamic capabilities: the nature and microfoundations of (sustainable) enterprise performance. Strategic Management Journal, 28 (13), 1319-1350.

Teece, D.J., Pisano, G., \& Shuen, A.M.Y. (1997). Dynamic capabilities and strategic management. Strategic Management Journal, 18(7), 509-533.

Ter Wal, A.L.J., Criscuolo, P., \& Salter, A. (2017). Making a marriage of materials: the role of gatekeepers and shepherds in the absorption of external knowledge and innovation performance. Research Policy, 46(5), 1039-1054.

Todorova, G., \& Durisin, B. (2007). Absorptive capacity: valuing a reconceptualization. Academy of Management Review, 32(3), 774-786.

Tortoriello, M. (2014). The social underpinnings of absorptive capacity: the moderating effects of structural holes on innovation generation based on external knowledge. Strategic Management Journal, 36(4), 586597.

Tsai, W. (2001). Knowledge transfer in Intra-organizational networks: effects of network position and absorptive capacity on business unit innovation and performance. Academy Management Journal, 44(5), 9961004.

Tuominen, M., \& Hyvönen, S. (2004). Organizational innovation capability: a driver for competitive superiority in the marketing channel. The International Review of Retail, Distribution and Consumer Research, 14(3), 277-293.

Vader, R., Martin, M., \& Qian, J. (2020). The realities of retailing in a COVID-19 world. Available at: https://home.kpmg/xx/en/home/insights/2020/03/realities-of-retailing-in-covid-19-world.html. 25 December 2020.

Van Den Bosch, F.A., Van Wijk, R., \& Volberda, H.W. (2003). Absorptive capacity: Antecedents, models, and outcomes. In Handbook of Organizational Learning and Knowledge Management. Hoboken, NJ, USA: Blackwell. 
Volberda, H.W., Foss, N.J., \& Lyles, M.A. (2010). Absorbing the concept of absorptive capacity: how to realize its potential in the organization field. Organization Science, 21(4), 931-951.

Wang, C.H., Lu, I.Y. \& Chen, C.B. (2008). Evaluating firm technological innovation capability under uncertainty. Technovation, 28(6), 349-363.

Wang, C.L. \& Ahmed, P.K. (2004). The development and validation of the organizational innovativeness construct using confirmatory factor analysis. European Journal of Innovation Management, 7(4), 303-313.

Weerawardena, J., \& McColl-Kennedy, J.R. (2002). New service development and competitive advantage: A conceptual model. Australasian Marketing Journal, 10(1), 13-23.

Winter, S. (2000). The satisficing principle in capability learning. Strategic Management Journal, 21, 981-96.

Wonglimpiyarat, J. (2010). Innovation index and the innovative capacity of nations. Futures, 42(3), 247-253.

Wu, J. \& Shanley, M.T. (2009). Knowledge stock, exploration, and innovation: research on the united states electromedical device industry. Journal of Business Research, 62(4), 474-483.

Xun, D. \& Xuehan, G. (2014). The effect of absorptive capacity on innovation performance: Empirical research on the mediating effects of knowledge transfer efficiency. BioTechnology an Indian Journal, 10(7), 1735-1740.

Yam, R. C. M., Guan, J. C., Pun, K. F., \& Tang, E. P. Y. (2004). An audit of technological innovation capabilities in Chinese firms: some empirical findings in Beijing, China. Research Policy, 33(8), 1123-1140.

Zahra, S.A. \& George, G. (2002). Absorptive capacity: a review, reconceptualization, and extension. Academy of Management Review, 27(2), 185-203.

Zheng, S., Zhang, W., \& Du, J. (2011). Knowledge-based dynamic capabilities and innovation in networked environments. Journal of Knowledge Management, 15(6), 1035-1051. doi:10.1108/13673271111179352.

Zook, C. \& Rigby, D. (2002). Open-market innovation. Harvard Business Review (October). 